\title{
INDUKCIÓS HEVÍTÉS HŐMÉRSÉKLET-IDŐ DIAGRAMJAI
}

\author{
Koncsik Zsuzsanna \\ egyetemi docens, Miskolci Egyetem, Anyagszerkezettani és Anyagtechnológiai Intézet \\ 3515 Miskolc-Egyetemváros, e-mail: zsuzsanna.koncsik@uni-miskolc.hu \\ Fodor Béla \\ tanszéki mérnök, Miskolci Egyetem, Energetikai és Vegyipari Gépészeti Intézet \\ 3515 Miskolc-Egyetemváros \\ Lukács János \\ egyetemi tanár, Miskolci Egyetem, Anyagszerkezettani és Anyagtechnológiai Intézet \\ 3515 Miskolc-Egyetemváros
}

\begin{abstract}
Absztrakt
Napjainkat a felgyorsult technológiai folyamatok jellemzik. A hökezelési technológiákban az egyik leghatékonyabb eljárás az indukciós hevités, amelynek révén a klasszikus edzési-megeresztési folyamat idötartama akár tizedére is csökkenhet. Azonban ezt a felgyorsult folyamatot nehéz a szokásos hökezelési diagramokkal jellemezni, már csak azon egyszerü tény miatt is, hogy nincs maximális kemence hömérséklet, hanem csak az indukciós tekercs leadott teljesitménye értelmezhetö, amely a hökezelt alapanyagban meghatározott nagyságú höt kelt. A hökezelési diagramok segitségével jellemezhetö a kialakuló szövetszerkezet és elöre jelezhető a mechanikai viselkedés. Jelen cikkben adott geometriájú alkatrész indukciós hevitése közben mérhetö maximális hömérsékleteket vizsgáljuk, hökamera segitségével és a hevitési, valamint a hülési idők meghatározásával kisérletet teszünk hömérséklet-idö diagramok felrajzolására.
\end{abstract}

Kulcsszavak: indukciós hevités, hömérséklet-idö diagram, hökamera

\begin{abstract}
Our days are characterised by accelerated processes. In heat treatment technologies one of the most effective processes is induction hardening. Due to the induction hardening the time range of classic hardening-tempering processes can be decreased to tenth. However, the characterisation of this accelerated process is complicated with the common time-temperature diagrams, because of the simple fact, that there exists no maximal chamber temperature, only the given power of the induction coil can be given, which causes determined heat in the heat-treated base material. Based on heat-treatment diagrams, the forming microstructure can be characterised, and the mechanical behaviour can be predicted. In this paper the maximum temperature of a component with given geometry is examined during induction hardening, applying thermal camera and based on the experimental results and the determined heating and cooling times, time-temperature diagrams are drawn.
\end{abstract}

Keywords: induction hardening, time-temperature diagram, thermal camera

\section{Bevezetés}

A 20. és a 21. század fordulójának felgyorsult ipari folyamatai magukkal hozták a hőkezelési technológiák gyorsításának a szükségességét is. Az indukciós hevítés, mint rendkívül hatékony hökezelési 
technológia, a hőkezelési időt jelentősen lecsökkenti, miközben a technológia végeredményeként a hagyományos hőkezelési eljárásokkal azonos állapotú anyag (gyártmány) keletkezik. Az eljárás technológiája teljesen más elven alapul, mint a hagyományos hevítő kemencés eljárásoké.

Az indukciós edzés abban különbözik a többi felületedzési eljárástól, hogy a hőt nem kívülröl viszszük be, hanem az magában az alkatrészben keletkezik. Az induktor kialakításával és a technológiai paraméterek célzott beállításával érhető el, hogy a hőfejlődés a darab azon helyén menjen végbe, ahol arra szükség van. Az indukciós hevítés segítségével lényegesen nagyobb teljesítménysürüség érhetö el, mint a többi felületedző eljárás során, ezért a hevítési sebesség igen nagy. Emiatt lényegesen lecsökken a szükséges hevítési idő, ebböl következik, hogy az eljárás nagyon gazdaságos és termelékeny. Emellett a folyamat ismételhetősége is kiváló, mivel a villamos paraméterek pontosan és jól szabályozhatók [1], [2].

A darabok sokfélesége és az edzett kéreg tulajdonságainak különbözősége miatt többféle indukciós edzési eljárás alakult ki. Ezen sokféle eljárást két nagy csoportba lehet besorolni, az edzési metódus szerint.

A két nagy csoport a következő:

- single-shot hardening (teljes felület egyidejü edzése), ahol álló induktor hevíti a munkadarab egész edzési zónáját, majd az edzési hőmérséklet elérése után gyors lehütést alkalmaznak;

- scanning hardening (pásztázó edzés), ahol egyszerre csak a munkadarab egy kis részének edzése folyik, az induktor és edzőgyürü egy szerszámként mozog a darabon és a hevítést követően rögtön megtörténik az edzés is.

Ebből a két alap eljárásból alakultak ki a további eljárásváltozatok, mivel ezek nem fedik le teljes egészében a valóságban szükséges és használatos eljárásokat [3], [4].

Az acélok hőkezelése során bennük átalakulások, szövetszerkezeti változások mennek végbe. A jelenlevő szövetelemek fajtája és mennyisége az ötvözet tulajdonságait döntő módon meghatározza. Ezért fontos az egyes hőkezelések alkalmával lejátszódó fázisátalakulások, a keletkezett szövetelemek ismerete. A hökezelési hőciklusok ismeretében a hőkezelés alatt bekövetkező változások követhetők, amennyiben rendelkezésre állnak a megfelelő segédletek. Mint ismeretes, az acélok átalakulása, a keletkezett szövetelemek minősége és mennyisége a vizsgált acél kémiai összetételén kívül a hevítés és a hűtés körülményeitől is függ. A megfelelő hőmérsékletre való hevítés közben kialakuló ausztenit jellemzői (stabilitás, homogenitás, szemcseméret) függnek a hevítés sebességétől, véghőmérsékletétől, a hőntartás idejétől. Az átalakulás közben keletkezett szövetelemeket az ausztenitesítési diagramok jelenítik meg egy adott acélra. A hevítés és hőntartás során kialakult homogén ausztenitből a hütés viszonyaitól függően különbözö szövetelemek keletkezhetnek, amelyekre információt az izotermás, vagy a folyamatos hütésre érvényes átalakulási diagramok szolgáltatnak, egy-egy adott acél összetétel esetén. A gyakorlatban minden egyes acél adagra, összetételre nem áll rendelkezésre sem ausztenitesítési, sem átalakulási diagram; általában egy-egy szabványos acélminőségre rendelkezünk csak információkkal. Az évtizedes tapasztalatok alapján ez a gyakorlat számára megfelelő megbízhatóságú információt ad a fázisátalakulásokra és a kialakult szövetelemek minőségére, mennyiségére, továbbá az adott acél néhány jellemző tulajdonságára (például keménység).

Az indukciós edzés során az anyagban végbemenő folyamat, a vas-karbon anyagokra jellemző átalakulási folyamat. Az acélt elöször az $\mathrm{A}_{3}$ vonal feletti hőmérsékletre kell hevíteni. Az indukciós edzés során ugyanaz a folyamat megy végbe, mint kemencében való edzéskor, csak gyorsabban [3]. Kemencében való edzéskor elegendő idő van arra, hogy a szövetszerkezet teljesen ausztenitesedjék. Elöször a perlit, később a ferrit alakul át ausztenitté a hőmérséklet növekedésével. Ennek a két szövetnek a karbontartalma különböző (perlit 0,8; ferrit < 0,01). Ez a különbség diffúzióval egyenlítődik ki a hevítési folyamat során. Erre a gyors indukciós edzés során nincs elég idő. Tehát magasabb hőmérsékletre 
kell hevíteni (lásd 1. ábra), mivel a diffúzió a hőmérséklet növekedésével egyre intenzívebbé válik. A hevítés következtében az anyagból homogén ausztenit képződik, az előtte kötött karbon az ausztenitben oldott állapotban lesz jelen. A folyamat rendkívül gyors lejátszódása miatt szemcsedurvulásra nem kell számítani.

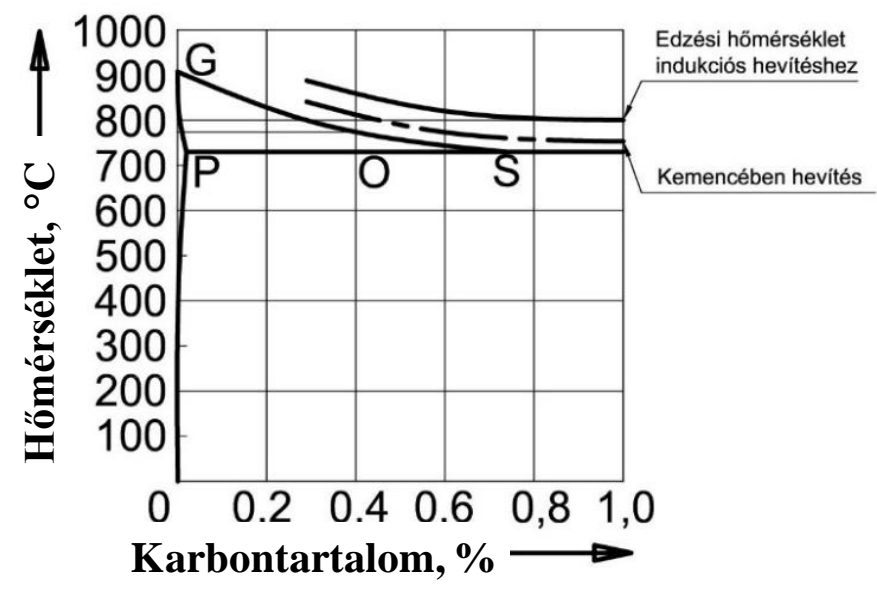

\section{1. ábra. Hevitési hömérséklet [5]}

Ezután a lehütést olyan gyorsan kell elvégezni, hogy a karbon a lehütés után is oldva maradjon. Így keletkezik az edzési szövetszerkezet, a martenzit. Bár az alkalmazott hütési sebesség csak a felületen tud érvényesülni, ha a lehütés túl lassú, akkor az ausztenitből perlit és ferrit keletkezik. A martenzitképződés következtében bekövetkezö keménységnövekedés csak akkor jelentős, ha az acél karbontartalma $0,35 \%$-nál nagyobb volt [2]. A keménység $0,8 \%$ karbontartalomig tovább növekszik, a fölött pedig már nem jön létre jelentős keménységnövekedés [2]. A nagy karbontartalom következtében az ausztenit martenzitté alakulása alacsony hőmérsékleten megy végbe, sőt esetleg még szobahőmérsékleten sem megy végbe teljesen. Túlhütéssel a maradék ausztenit még martenzitté alakítható, azonban, ha ez nem történik meg, akkor a maradék ausztenit idővel többnyire bénitté alakul. Az edzéssel elöállított martenzit kemény, de rideg is. Fajlagos térfogata nagyobb, mint a kiindulási szöveté. Ez a fajtérfogatnövekedés belső feszültségeket okoz. Ez a felületi edzés során jelentősebb, mivel nem a teljes szövetszerkezet lesz martenzites. Ez a feszültség és a mag és kéreg közötti hömérsékletkülönbségböl keletkező feszültség okozhat a későbbiekben edzési vetemedést vagy a feszültség miatt kialakulhatnak repedések. Erre a problémára a megoldás a megeresztés, amely a martenzit rácsszerkezetében okoz változásokat. Ennek következtében csökken az edzés során létrejött belső feszültség. A megeresztés következtében a technológiai paraméterek függvényében, kismértékü keménységcsökkenéssel kell számolni, míg a mechanikai tulajdonságok (nyúlás, szívósság) kedvezően változnak [2].

\section{Kísérleti körülmények}

Az indukciós hevítés hőmérséklet-idő diagramjainak felvételéhez autóipari alkalmazásban is használt, C45 anyagminőségü, $30 \mathrm{~mm}$ átméröjü, $564,5 \mathrm{~mm}$ hosszúságú rúd alakú próbatesteket használtunk, amely próbatestek egyik vége fogazott volt, $164 \mathrm{~mm}$ hosszon.

$\mathrm{Az}$ alkalmazott indukciós hevítési folyamat az ún. scanning hardening, azon belül is előtolókeringető eljárás. Az eljárás során az induktor geometriája a fogazott rész keresztmetszetét követi, így a fogazat megfelelö egyenletes hevítését lehet biztosítani. A fogazati részen fluxuskoncentrátor van 
felszerelve, ezzel a fogazat számára szükséges extra energiát lehet bevinni, így a fogakat teljesen át lehet edzeni. Ezt a nem szimmetrikus induktorformát úgy lehet kiküszöbölni, hogy a teljesen hengeres részek edzése során a fogasléc forog. Az induktorban, annak teljes hossza mentén, hütócsatorna található, amelyben az induktor hütőfolyadéka kering, így hütve azt. A hevítést a generátor teljesítményével és az induktor előtolási sebességével lehet változtatni. A frekvencia állandó értékü $\mathrm{f}=6,2 \mathrm{kHz}$ volt. A próbatestet a vizsgálat idejére gondolatban három szakaszra osztottuk. A hengeres részen azonos előtolási sebesség $(1700 \mathrm{~mm} / \mathrm{min})$ mellett az első szakaszon az induktor teljesítménye $74 \%$-os volt, míg a második szakaszon 55\%-os. A fogazott részen az induktor teljesítménye $54 \%$-os volt és álló, scannelő mozgást végzett $800 \mathrm{~mm} / \mathrm{min}$-es fordulatszámmal. A próbatesten beállított különbözö szakaszok hossza: az első szakasz: $254,5 \mathrm{~mm}$, a második szakasz: $146 \mathrm{~mm}$, míg a fogazat szakasza: $164 \mathrm{~mm}$. A kísérleti vizsgálat beállításai, mind az induktorra, mind az alapanyagra vonatkozóan egy autóipari gyártásban alkalmazott indukciós hevítés modellezését szolgálták.

A hütést, edzést egy, az induktor után közvetlenül bekötött edzőgyürủ végzi el, amibe a megfelelő minőségű edzőközeg adagolható. Jelen kísérletekhez ezt az edzőgyürüt eltávolítottuk, annak érdekében, hogy a maximális hevítési hömérsékletet mérni tudjuk.

A kísérletek során Jenoptik VarioCAM research 680 típusú hordozható mikrobolométeres hőkamera alkalmazására került sor. A mozgó induktor és forgó darab miatt nem volt lehetőség kontakt elven müködő hőmérsékletmérő módszert alkalmazni, és a hőelem, ellenálláshőmérő vezetékezését sem volt lehetőség rögzíteni a hőkezelési folyamat sajátosságai miatt [6], [7]. Emellett, a fogasléc teljes hosszában szükség volt a hőmérsékleteloszlás meghatározására, így a pirométer segítségével nagyszámú mérést kellett volna elvégezni. Mindezekől következően a megfelelő megoldást a hőkamera jelentette.

A hőkamera föbb tulajdonságai a következők [8]:

- képfelbontás: $640 \times 480$;

- méréstartomány: $-40 \ldots 1600{ }^{\circ} \mathrm{C}$;

- termikus felbontás: $30 \mathrm{mK}$;

- mérési pontosság: $\pm 1,5^{\circ} \mathrm{C}$, értéke független a mérési távolságtól;

- képfrissítési frekvencia: $50 \mathrm{~Hz}$.

A kamerához több optika is elérhető, a mérések során széles látószögü optika került alkalmazásra. A kamera 2,5 m távolságból rögzítette az adatokat, 16,67 Hz adatrögzítési frekvenciával, három párhuzamos mérést elvégezve.

A mérést megelőzően egy kalibrációs mérésre volt szükség, mivel a vizsgált anyagminőségü próbatest emissziós tényezője, amely a test hősugárzás-kibocsátási képességének mértékét jelenti, ismeretlen volt. Így pontosításra volt szükség a hőkamera által mért értékhez. Emellett kérdéses volt az is, hogy a hőkamera képes-e követni a gyors hőmérsékletváltozást. Ehhez a hőkamera és a Gleeble 3500as termo-mechanikus fizikai szimulátor segítségével ellenőrző, kalibrációs mérések elvégzése volt szükséges [9].

\section{Kísérleti eredmények}

A kamera által rögzített hőképek (lásd 2. ábra) kiértékelésére az IRBIS 3 Professional nevü szoftver segítségével került sor. A kiértékelés során, a teljes tengely hevítéséről készült képsorozat alapján, minden szakaszon, az induktor elhaladását követően mérhető maximális hőmérsékleteket határoztuk meg, a fogazott részen külön a fogtetőn és a fogárokban. A mérés során kizárólag a felület hőmérsékletét tudjuk mérni a hőképek alapján, illetve csak azokról a pontokról (pixelekről) kapunk megbízható információt, amelyekre a kamera pontosan merölegesen ,látott rá”, ezért is látszanak pixelesnek a 
felvételek. A bármely szögből érkező információk (fog oldallap, fogtő görbülete, fogárok görbülete) óvatossággal kezelendők.

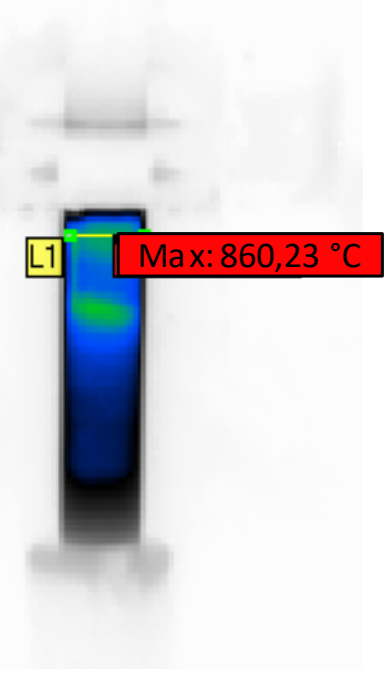

a)

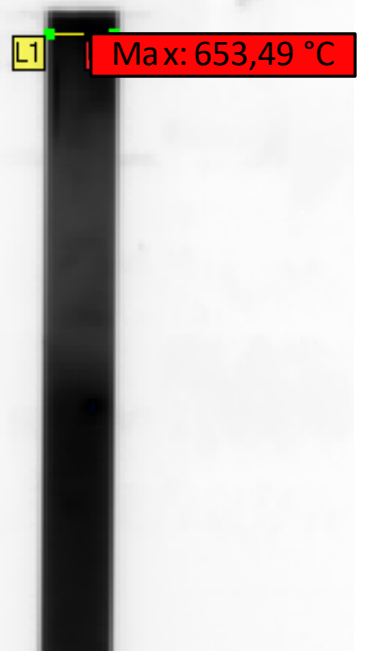

b)

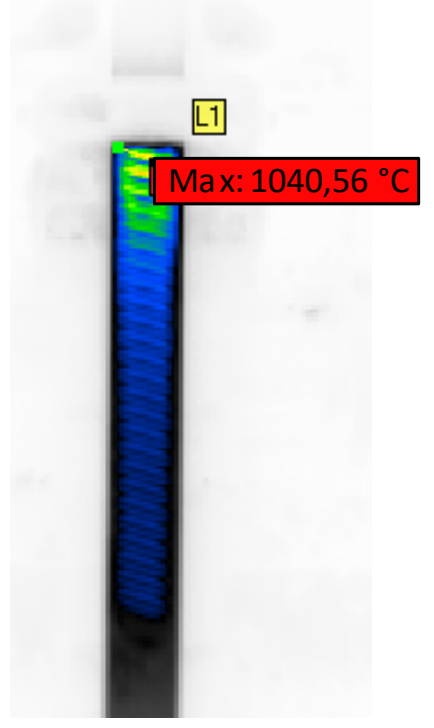

c)

2. ábra. a) Az első szakaszon mért maximális hömérséklet; b) a második szakaszon mért maximális hömérséklet, c) a fogazaton mért hömérséklet

A különböző szakaszokon, három párhuzamos mérés során mért maximális hőmérséklet értékeket az 1. táblázat tartalmazza. A három szakasz eltéró hőmérséklet értékei az egyes szakaszokon alkalmazott különböző induktor-teljesítményből fakad.

1. táblázat. A hömérséklet-idö diagramok szerkesztéséhez javasolt maximális hömérséklet tartományok a próbatest különbözö szakaszain

\begin{tabular}{|c|c|c|c|c|}
\hline \multirow{2}{*}{$\begin{array}{c}\text { Technológiai terület } \\
\text { felosztás }\end{array}$} & \multirow{2}{*}{$\begin{array}{c}\text { Első } \\
\text { szakasz }\end{array}$} & Második & \multicolumn{2}{|c|}{ Fogazat } \\
\cline { 4 - 5 } & szakasz & fogárok & fogtető \\
\hline Hömérséklet tartományok, ${ }^{\circ} \mathrm{C}$ & $860-880$ & $635-680$ & $860-900$ & $1040-1045$ \\
\hline
\end{tabular}

A klasszikus hőmérséklet-idő diagramok szerkesztéséhez nem elegendő a hevítéskor tapasztalt maximális hőmérséklet értékek megadása, hanem ismerni kell a hevítés, a hőntartás és a tényleges edzési folyamat során a hütés idejét is. Ezen idők megadása az induktor tényleges mozgása alapján történt. A 2. táblázat tartalmazza a kísérleti munka során tapasztalt hevítési, hőntartási és hütési időket.

2. táblázat. A hömérséklet-idö diagramok szerkesztéséhez szükséges idő értékek

\begin{tabular}{|l|c|c|c|c|}
\hline $\begin{array}{c}\text { Technológiai terület } \\
\text { felosztás }\end{array}$ & Hevítési idő, s & Hőntartási idő, $\mathbf{s}$ & $\begin{array}{c}\text { Hütési idő, } \\
\text { alsó pont, } \mathbf{s}\end{array}$ & $\begin{array}{c}\text { Hütési idő, felső } \\
\text { pont, } \mathbf{s}\end{array}$ \\
\hline Első szakasz & 0,85 & 0,37 & 37,28 & 30,72 \\
\hline Második szakasz & 0,85 & 0,37 & 30,72 & 26,22 \\
\hline Fogazat & 1,8 & 0,80 & 24,22 & 11,22 \\
\hline
\end{tabular}


A hevítési idő az az idő, amíg az induktor teljes vastagságában elhalad egy adott pont fölött, vagyis amíg ténylegesen hevít, függ az alkalmazott előtolási sebességtől is. A hőntartási idő az az idő, ami az induktor elhaladása és az edzőközeg felületre érkezése között eltelik (a tényleges indukciós edzés során), az induktor felső vonalának és az edzőgyürü felső vonalának távolságából számítható, illetve szintén figyelembe kell venni az előtolás sebességét is. A hütési idő az az idő, amíg az edzőközeg az adott pontot hủti, ez az alsó pontoknál, amelyek hamarabb érintkeznek az edzőközeggel hosszabb, míg a felső pontoknál, amelyek később érintkeznek az edzőközeggel, rövidebb idő.

A mért hőmérsékletek és a számított idők alapján a különböző szakaszokra a hőmérséklet-idő diagramok megrajzolhatók. Az eredményeket a 3-5. ábrák illusztrálják.

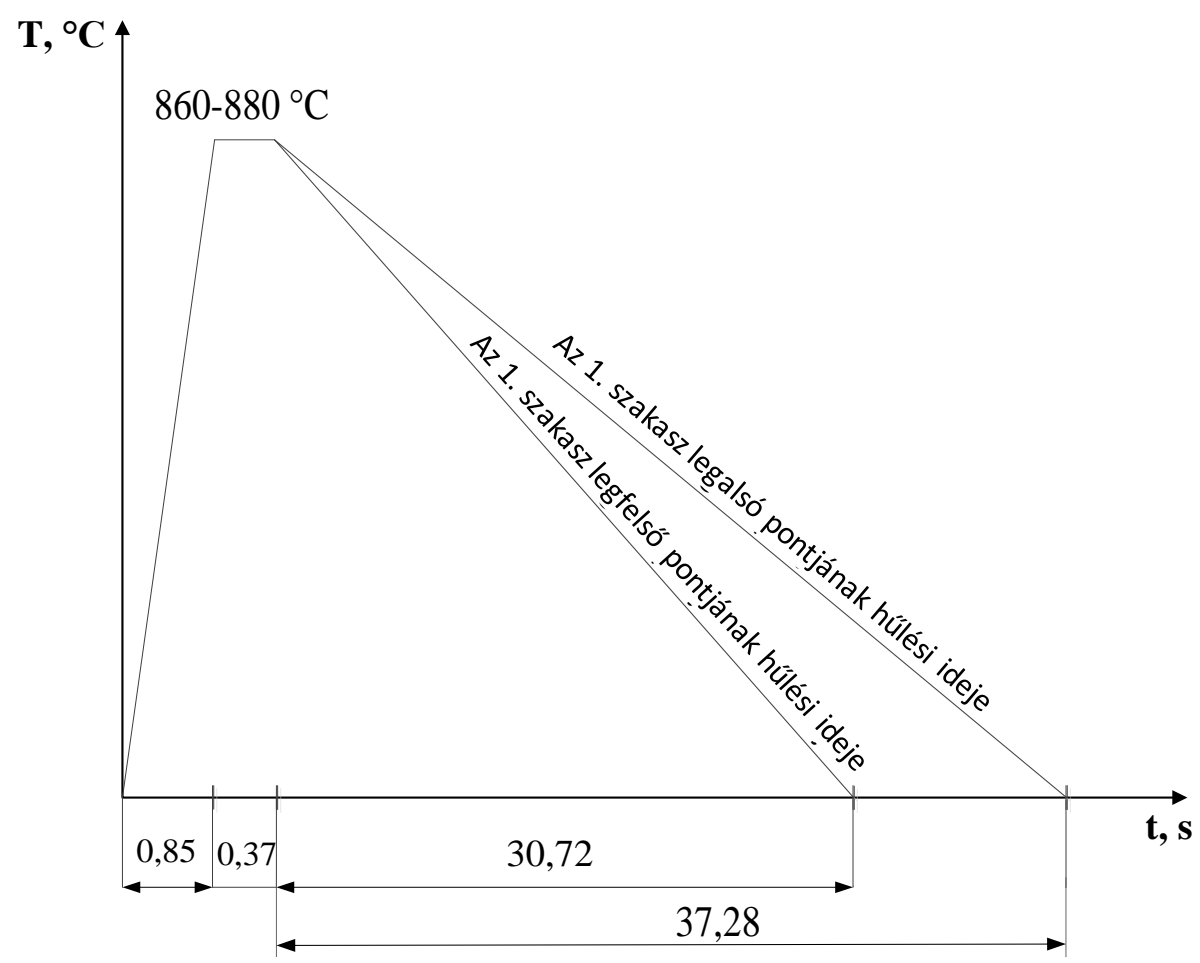

3. ábra. Az első szakasz hömérséklet-idö diagramja

A 3-5. ábrákon bemutatott diagramok alapján az első szakaszon beállított nagyobb induktor teljesítmény magasabb hőmérsékletet eredményezett, amely a második szakaszon (lásd 4. ábra) a teljesítmény csökkenésével lecsökkent. A fogazat esetében a fogak tetejét és a fogárkok hőmérsékletét tudtuk elemezni. A vizsgált fogak tetejének hőmérséklete alapján az anyag homogén ausztenites állapotban van, sőt még túl is hevül. A fogárokban mért hőmérsékletek is az $A_{3}$ hőmérséklet fölötti területre esnek. A fogprofilon, a fogtetőtől a fogárok felé haladva, a felület maximális hőmérsékletének enyhe csökkenésével kell számolni. A fogtető és a fogárok között elhelyezkedő fogprofil pontjaitól, arra közel merőlegesen a fog belső része felé haladva egy közel állandó hőmérsékletű tartományt követően a hőmérséklet csökken. Ebböl következik, hogy a keletkezett ausztenit nem feltétlenül homogén, sőt indukciós edzés elötti szövetelemek is maradhatnak az acélban, ha a fogtetőtől és fogprofiltól kellően eltávolodunk. 


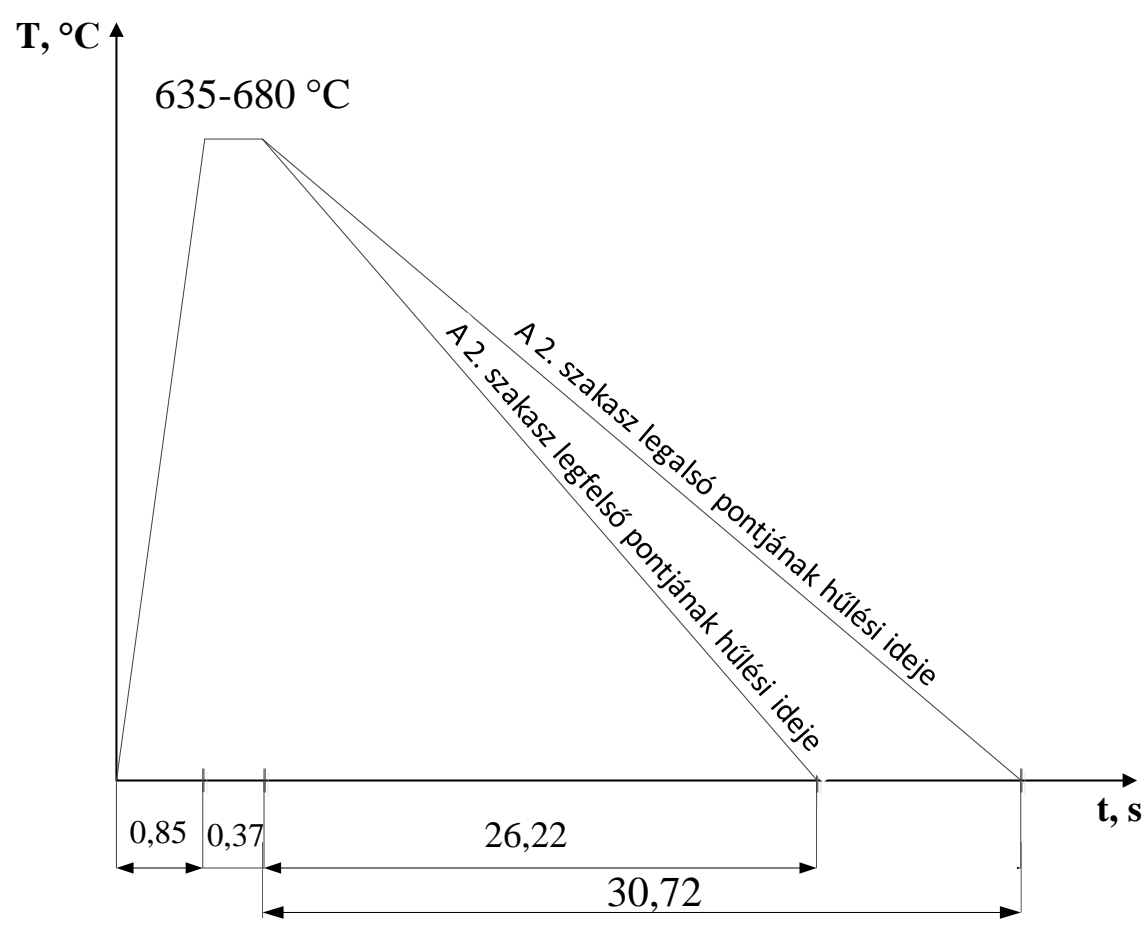

4. ábra. A második szakasz hömérséklet-idö diagramja

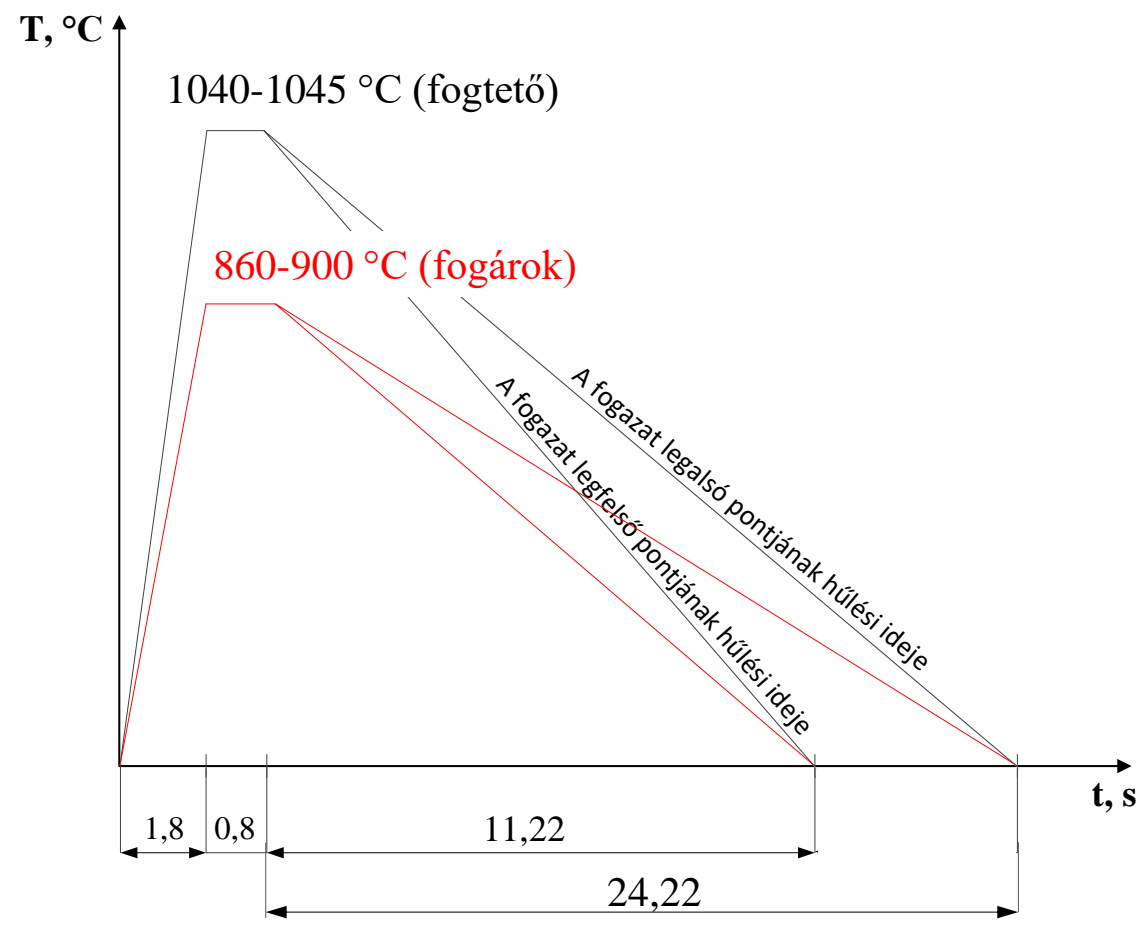

5. ábra. A fogazat hömérséklet-idö diagramja 


\section{4. Összegzés}

A közleményben bemutatott méréstechnika alkalmas a rendkívül gyors lefolyású indukciós hevítés klasszikus hőmérséklet-idő diagramjának meghatározására. A hőkamerás hőmérsékletmérés eredményei és azok alapján rajzolt hőmérséklet-idő diagramok lehetőséget teremtenek a felhevítés során kialakuló szövetszerkezet meghatározására, amelynek ismerete alapvető fontosságú a hőkezelt termék későbbi felhasználása, alkalmazhatósága szempontjából. A hőkezelés során fellépő maximális hőmérsékletek ismerete támpontot nyújthat továbbá a speciális kialakítású geometriák indukciós hevítése során fellépő hőfeszültségeiből adódó problémák megelőzésére, kiküszöbölésére.

\section{Köszönetnyilvánítás}

A cikkben ismertetett kutató munka az EFOP-3.6.1-16-2016-00011 jelü „Fiatalodó és Megújuló Egyetem - Innovatív Tudásváros - a Miskolci Egyetem intelligens szakosodást szolgáló intézményi fejlesztése" projekt részeként - a Széchenyi 2020 keretében - az Európai Unió támogatásával, az Európai Szociális Alap társfinanszírozásával valósul meg.

\section{Irodalom}

[1] Rudnev, V., Loveless, D., Cook, R. L., Black, M.: Handbook of induction heating, Madison Heights, Michigan, U.S.A: Marcel Dekker, Inc., 2003., 796. p, ISBN 0824708482

[2] Dezső, B. S.: Indukciós hevités, Budapest, Müszaki Könyvkiadó, 1965., 508. p, ETO 6213655

[3] Rapoport, E., Pleshivtseva, Y.: Optimal control of induction heating processes, 2007., 349. p, ISBN 9780849337543 https://doi.org/10.1201/9781420019490

[4] Berggren, K., Leif, M.: Induction hardening - A quick guide to methods and coils, Technol. Pract., vol. 2, (2014) pp. 97-98.

[5] Benkowsky, G.: Részlet a vas-szén diagramból, in Indukciós hevítés, 1984, p. 94/3.

[6] Axiomet, Hömérsékletérzékelők és mérési módszerek. [Online]. Available: https://hu.axiomet.eu/page/2096/Homersekleterzekelok-es-meresi-modszerek. [elérhető: 2020. 02. 26.].

[7] Nunes, R. M.: ASM Handbook, Volume 4, Heat Treating. ASM International, 1991., 2173. p, ISBN 0871703793

[8] Jenoptik VarioCam. https://www.jenoptik.com/products/cameras-and-imagingmodules/thermographic-camera/handheld-thermographic-camera. [elérhetö: 2020.02.26.].

[9] Koncsik, Zs., Fodor, B., Kubuk, D., Losonczy, R.: Hökezelési hömérsékletek mérése indukciós hevités során, Gépgyártás, LVIII. évfolyam, 1-2. szám, (2019) pp. 40-44. 